IZA DP No. 5138

Independent Individual Decision-Makers in Household Models and the New Home Economics

Shoshana Grossbard

August 2010 


\title{
Independent Individual Decision-Makers in Household Models and the New Home Economics
}

\author{
Shoshana Grossbard \\ San Diego State University, \\ Universidad de Zaragoza and IZA
}

Discussion Paper No. 5138

August 2010

\author{
IZA \\ P.O. Box 7240 \\ 53072 Bonn \\ Germany \\ Phone: +49-228-3894-0 \\ Fax: +49-228-3894-180 \\ E-mail: iza@iza.org
}

Any opinions expressed here are those of the author(s) and not those of IZA. Research published in this series may include views on policy, but the institute itself takes no institutional policy positions.

The Institute for the Study of Labor (IZA) in Bonn is a local and virtual international research center and a place of communication between science, politics and business. IZA is an independent nonprofit organization supported by Deutsche Post Foundation. The center is associated with the University of Bonn and offers a stimulating research environment through its international network, workshops and conferences, data service, project support, research visits and doctoral program. IZA engages in (i) original and internationally competitive research in all fields of labor economics, (ii) development of policy concepts, and (iii) dissemination of research results and concepts to the interested public.

IZA Discussion Papers often represent preliminary work and are circulated to encourage discussion. Citation of such a paper should account for its provisional character. A revised version may be available directly from the author. 
IZA Discussion Paper No. 5138

August 2010

\section{ABSTRACT}

\section{Independent Individual Decision-Makers in Household Models and the New Home Economics*}

Much of the recent literature in household economics has been critical of unitary models of household decision-making. Most alternative models currently used are bargaining models and consensual models, including collective models. This paper discusses another alternative: independent individual models of decision-making that don't make any specific assumptions of jointness of decision-making in households. Unitary models are typically associated with Gary Becker even though most of Becker's own analyses of the family did not use his unitary model. This is especially the case with the specifically independent individual models presented in his theory of marriage. Decision-making models assuming independent individual household members in the Becker tradition are reminiscent of models of labor markets in which firms and workers are independent decision-makers. As basis for econometric estimations, such models may be preferable to models imposing the structure of a game or a household welfare function.

JEL Classification: D11, J00

Keywords: $\quad$ unitary model, household model, Gary Becker, marriage, labor

Corresponding author:

Shoshana Grossbard

Department of Economics

San Diego State University

San Diego CA 92182-4485

USA

E-mail: shosh@mail.sdsu.edu

\footnotetext{
* To appear in Household Economic Behaviors edited by J. Alberto Molina. Springer, forthcoming.
} 


\section{Introduction}

Much of the recent literature in household economics has been critical of unitary models in which households act as monolithic blocs possibly led by a male benevolent dictator. ${ }^{1}$ Gary Becker, who authored a well-known unitary model assuming a benevolent altruist (Becker 1976), is often associated with that model. ${ }^{2}$ This unitary model has also been associated with the New Home Economics (NHE) pioneered by Becker and Jacob Mincer in the 1960s. ${ }^{3}$ For instance, Elizabeth Katz (1997) wrote: “Becker's model of the household (alternatively referred to as the common preference model, the unitary approach or the New Home Economics)..."

Critics of unitary models have proposed to replace these models with models assuming that in multi-person households decisions are made by individuals who have their own preferences and their own constraints. The alternative models proposed by the critics include bargaining models and consensual models. Bargaining models assume that households play games of a cooperative (e.g. McElroy and Horney 1981) or a noncooperative (e.g. Konrad and Lommerud 1995) nature. Non-bargaining models, such as Chiappori (1988) or Apps and Rees' (1988) model, follow Samuelson's (1956) consensual approach and assume that households have a social welfare function (SWF).

These alternatives to the unitary models impose a structure of jointness in the decision-making by individual household members, either in the form of a game that is supposedly played or a SWF that the household adheres to. There is another alternative to unitary models: independent individual models of decision-making that don't make any specific assumptions of jointness of decision-making in households. Such models can be as useful for framing econometric estimations as the bargaining or SWF models while not entailing restrictions following from jointness assumptions.

Some of the most influential models in household economics authored by Becker can be interpreted as 'independent individual' models. They first appeared while he was working with Jacob Mincer at Columbia in the 1960s, when together they started the NHE, before his specifically unitary models that appeared in the 1970s and 1980s. What the recent literature seems to overlook is that Becker has offered a palette of models, the equivalent of an artist's palette of colors. In most of his own empirical work on the family Becker refrained from referring to an explicitly unitary framework. Some of the work of others in the NHE tradition, including Mincer, can also be interpreted with independent individual decision-making models. The NHE has many models that are consistent with the assumption that individual members of a household are independent decision-makers. More generally, whether associated with the NHE or not, few researchers have adopted the altruistic dictator model or other explicitly unitary models as the basis for their empirical models analyzing household outcomes.

This chapter first examines what is wrong with unitary models. Section 3 defines household economics and opens the door to independent individual household models,

\footnotetext{
1 The term 'unitary' was coined by Browning et al (1994).

${ }^{2}$ References to Becker's unitary model can be found in articles on a diverse range of applications of household economics, ranging from labor supply--such as Chiappori (1988), Chiappori, Fortin and Lacroix (2002), Chau, Li, Liu and Zhang (2007)--, to fertility (including Tiefenthaler (1999) and Klawon and Tiefenthaler (2001)), care work (e.g. Bergeron 2009), child labor and school attendance--such as Emerson and Souza (2007)--and demand for pets (see Schwarz, Troyer, and Walker 2007).

3 The NHE was called 'New' to distinguish applications of household economics based on economic analysis from 'Home Economics', an academic discipline that was then very popular in the U.S.A. and focused on the training of high school students in practical home management skills, including sewing and woodwork.
} 
including models of decision-making by single households. The tradition of independent individual models goes back at least to Robbins' (1930) individual labor supply model, which is presented and discussed in Section 4. Section 5 is about Becker's allocation of time model, Becker's (1965) standard independent individual decision-making model. The 1965 model antedates the bargaining models (such as Manser and Brown 1980 and McElroy and Horney 1981) and 'individual' models that are specific about individual members of a household making decisions independently, such as parts of Becker (1973). Section 6 places Becker (1965) in the context of Becker's contributions to economics of the family and that of independent individual models in the tradition of the NHE. Section 7 discusses unitary models from the perspective of Becker students at Chicago in the 1970s. Conclusions are found in Section 8.

Independent individual decision-making models in the NHE tradition, developed by Becker and his students, tend to be overlooked in recent studies of couples and families. This chapter aims at rectifying this oversight and help correct misperceptions regarding the place of unitary models in the NHE and the economics of the family.

\section{Righting the wrongs of unitary models}

Models assuming that multi-person households act as if they were one unit are problematic. First, as has been mentioned by all critics of unitary models, such models imply that it does not matter who within the household earned a particular income. Apps and Rees (2009) call this the anonymity implication. As is well documented in Woolley (2003) this implication of anonymity does not hold based on numerous studies of consumption and personal finance. In contrast, the models proposed by the critics of the unitary model recognize that it matters who earns income in a household.

Second, it follows from unitary models that factors affecting the remarriage prospects of individual members of a couple — such as sex ratios in marriage markets--will have no effect on the consumption or labor supply of these individual members. This is a problem that critics of the unitary model have addressed: they proposed that factors such as sex ratios be included as explanatory variables in studies of labor supply or consumption. McElroy (1990) coined such factors EEP and Browning et al. (1994) 'distribution factors'.

Third, the assumptions behind unitary models are often unappealing. For example, consider Becker's often-cited unitary Rotten Kid model of an altruistic dictator making decisions for household members he cares about (Becker 1976 and Chapter 8 in Becker 1981). ${ }^{4}$ The assumptions behind this model are offensive to the sensitivity of women if the dictator is a man, as is the case of all of the examples Becker used in print (see Barbara Bergmann's (1995) critique in the first issue of Feminist Economics). Orally, Becker has accepted that the dictator could be a woman. ${ }^{5}$ It would also be highly unrealistic and offensive to men if models assumed that women dictate their will on their husband and children. The critics of Becker's unitary model (Becker 1976) have avoided all these problems by not relying on the existence of a benevolent dictator making decisions in the household.

One does not need to impose so much structure on couples or other multi-person households in order to right the wrongs of unitary models. Instead, one could use independent individual models. In such models the same factors that are sometimes called EEP or distribution factors also matter, and these models don't assume that households are

\footnotetext{
${ }^{4}$ Note that Becker (1991) is identical to Becker (1981) except for a new introduction.

${ }_{5}^{5}$ Personal recollection of the author while attending Becker's workshop in the years 1974-76.
} 
run by anyone, let alone a benevolent dictator. These models have the advantage of not requiring the strong assumptions needed by bargaining or SWF models.

Before taking a closer look at the range of models that are available for modeling behavior of household members we need to define household economics.

\section{Defining models of decision-making in households.}

Central components of this definition are the scope of the models, the nature of the decision-making agent, and assumptions regarding jointness of decision-making in multiperson households.

Scope. The scope of household decisions encompasses any outcome that originates on the 'household' side of the circular flow and possibly requires a decision by a household or any of its members. The circular flow is typically limited to conventional outcomes, such as consumption, labor supply, or the supply of loanable funds. As defined here, household decision-making models also address outcomes that became part of the territory of economics after its expansion into new areas of inquiry. In that sense, this article defines household economics in the spirit of the New Home Economics started by Becker and Mincer in the 1960s. It is then that economists started to apply utility maximizing models to frame decision-making about outcomes of great interest to households but traditionally not researched by economists, such as fertility, health production at home, wellbeing, number of wives, and type of marriage contract. In sum, the scope of the models surveyed here includes any outcome that possibly involves decision-making by a household or one of its members. From here onwards, I will use the term 'household model' to describe a model that frames decisions by households regarding any possible outcome.

The scope of the definition used here is wider than that of Samuelson's (1956) theoretical treatment of household decisions. Of central interest to Samuelson was the question of whether the body of standard propositions in economics-such as the law of demand-is compatible with the realization that households often consist of a number of people. Authors of economic models of the household who have followed Samuelson's tendency to focus on standard applications of economics such as consumption, savings, and labor supply include Apps, Bourguignon, Rees, and Woolley, and until recently, Browning and Chiappori.

Individual vs. Multi-Person Households. Some households consist of single individuals. The most individualistic household model involves a single individual with an individual utility function that does not include any terms reflecting others' wellbeing in the utility function and limited by constraints that solely involve personally owned resources. In some economic models such individual agents interact with others via voluntary exchanges possibly involving prices. The household models I consider include such completely individualistic models. They span the whole individualistic-collectivistic spectrum: from these most individualistic models to models that involve symbiotic relationships between two partners in line with the ideal of romantic love. At this other extreme there is no distinction between his and her consumption and the couple has one blended utility function and completely pooled resources. Most household models fall in between these two extremes and are often vague as to the exact nature of the interdependence between household members.

Most others use a more restrictive definition of household model and have limited their interest to households including more than one decision-maker. Such is the case of those who apply bargaining or SWF models, for these models only make sense if there are at least two members in a household. In contrast, the definition used here encompasses single households into the definition of household. 
Jointness of decision-making by multi-person households. SWF models such as Chiappori (1988) and Apps and Rees (1988) assume that in multi-person households there is some "joint decision taking". Bargaining models assume that individuals in households play either cooperative or non-cooperative games. In contrast, the definition used here does not limit household models to models assuming that multi-person households necessarily make joint decisions or react to each other in certain ways. The definition used here allows for the cohabitation of family members who are independent decision-makers. Not only do household members not necessarily cooperate, as is assumed in cooperative models of household decision-making, but they may not behave according to non-cooperative models of decision-making either, in the sense that such models view a need to establish equilibrium allocations for the household. Household models include the separate sphere model of Lundberg and Pollak (1993) in which household members are joint decision-makers regarding some outcomes and they maintain separate spheres regarding other outcomes. They also include independent individual models of decision-making in which individual members act in separate spheres all the time and there is no attempt to establish equilibrium allocations for the household (as is the case in Grossbard-Shechtman 1984).

The definition of household models used here is more general than that used by most authors, including the classification of household models by Apps and Rees (2009), in the sense that it:

1. Applies to unconventional applications of economics, such as the economics of marriage, health, and fertility.

2. Includes single households, and

3. Includes models that don't assume jointness in decision-making by members of multi-person households.

An example of a very popular and well-known model of decision-making by individuals in households is the standard model of labor supply. This model, presented in the next section, is often interpreted as an independent individual model of decision-making by members of multi-person households.

\section{The Individual Household Model of Labor Supply}

The classic work on Lionel Robbins (1930) on the leisure/goods trade-off continues to be very influential in labor economics. This quintessentially individualistic model consists of the following maximization problem:

(1) Max U (x, s)

s. t. a budget constraint $\mathrm{I}+\mathrm{wl}=\mathrm{px}$

and a time constraint $\mathrm{T}=1+\mathrm{s}$,

where $\mathbf{x}$ are commercial goods, $\mathbf{s}$ is leisure, $\mathbf{I}$ is non-labor income, $\mathbf{p}$ are prices and $\mathbf{x}$ is a composite commercial good.

The popularity of this model is evident from the prominent place it takes in introductory labor economics such as (Borjas 2009) and Ehrenberg and Smith (2009) and in the "labor economics" entry on Wikipedia (May 16, 2010). One of the reasons this model is so popular in textbooks is that it is widely used in empirical research on labor supply, even in research analyzing allocation of time by individuals who are part of a couple. Researchers typically include other household members' income, and possibly other characteristics of 
these other members, as parameters influencing an individual's choice between leisure and goods.

Given that labor supply studies may be one of the most important sub-fields of household economics as defined here, the prominence of independent individual models in that area is revealing. Labor economics tends to be a field focused on applied economics and not on theory, so this prominence indicates that from a pragmatic point of view, despite the proliferation of bargaining and consensual household models, empirical researchers often prefer to stick to the simpler models of individual behavior that don't impose restrictive assumptions as to how the members of a household deal with each other and that are generally as useful for framing an empirical model as the bargaining or SWF models.

What contributes to the model's usefulness for framing empirical work on labor supply and time use is that the model is applicable both to single households and to multi-person households such as couples. Most economists who use the model in the context of a multiperson household assume that each agent is acting independently, while taking account of the other household members' resources such as their income.

It is also interesting to examine this model that dominates in labor economics in order to extract its underlying assumptions about relationships between workers and firms and establish the relevance of these assumptions to analyses of household behavior. Standard models of labor supply and demand at the basis of much of the empirical literature, such as the literature on wage differentials, assume competitive labor markets and view firms and workers as independent decision-makers. They typically ignore the fact that firms are actually composed of individual agents, including workers, firm managers and firm owners. The use of bargaining models taking account of monopoly or monopsony power is limited in much of the empirical research in labor economics.

Why would households be so different from firms in that respect? The forces of competition before and after couple formation are likely to reduce the monopoly power of individual agents whether they are workers and firms, in the labor market context, or spouses-in the household and marriage market context.

There is some use of bargaining models among workers and firms, including collective bargaining, especially in the Industrial Organization literature less interested in labor supply and wage differentials. But what is really hard to find in labor economics are consensual models assuming that workers and the firm they work for have a shared SWF. It would not occur to most labor economists to assume that a firm and its workers need a consensually established rule for distribution of the surplus that the firm generates. It is too obvious that there are exogeneously established prices guiding the firm and its workers and that all the agents involved are independent decision-makers with separate utility functions and no comprehensive SWF inducing them to reach distribution rules by consensus. I don't see any good reason to assume that the small non-profit firms we call 'households' that produce goods and services at home are fundamentally different from firms producing goods and services using hired labor.

This basic model of labor supply had a strong influence on Becker's model of allocation of time, a very influential model that is a central part of the NHE tradition.

\section{Becker's model of allocation of time in the context of his economics of the family}

Becker (1965) published a theoretical model of decision-making that incorporated choice between labor and an alternative activity including both leisure and household production. The model has a single household utility function, a function of commodities $Z$ that can either be bought or produced at home. If we translate Becker's home-produced Zs 
into the factors of production used to produce them at home, the Becker model of allocation of time looks similar to the basic problem of labor supply presented above. The Becker (1965) model looks as follows:

(2) $\operatorname{Max} U(x, s)$

s. t. a budget constraint: $I+w l=p x$

and time constraint: $T=l+s$

These two constraints can be combined into a full income constraint:

$F I=(I+w T)=w s+p x$,

where $w s$ is the time cost of home-produced goods, assuming the individual participates in the labor force and earns a wage $w$, and FI is full income.

Becker's (1965) model of allocation of time is consistent with his altruist model in which the household acts as one unit led by a benevolent dictator. However, it is also consistent with completely different assumptions, including the assumption that two individuals live independently under the same roof, each having his or her own utility function and production function. This model can be understood as a model of behavior of single individuals, which is how it was presented in the first chapter in Becker's (1981) Treatise on the Family. Alternatively, the model can be interpreted for individuals in a twoperson household, typically either a husband or a wife, who act independently and take the other's income into account in their non-(own) labor income $I$. This is how many empirical models of labor supply frame the labor supply equation or earnings equation of a married man or woman (see for instance Bloemen and Stancanelli 2008). The partner's income is then considered non-labor income of the individual in focus.

With the relatively recent availability of time use data there has been much recent growth in economic research on allocation of time to household production. This research often uses Becker's individual model of allocation of time. Again, as in the case of labor supply studies, this is for pragmatic reasons. The model can be interpreted in terms of independent decision-making by individuals living in couples. Some recent econometric studies frame their analyses of time use in a manner that is consistent with the assumption of independent decision-making (see for instance Connelly and Kimmel 2010). Most empirical specifications related to time use include variables such as spouse's income and other characteristics without referring to a particular type of game or assumption about a couple's SWF.

If the Becker (1965) model is so influential and it does not require the assumption of a household unified by an altruistic head, why then are so many scholars associating Becker with the unitary model? Becker may have favored this interpretation. For instance, in section (e) Becker (1965) writes: "multi-person households also allocate the time of different members", which implies that the household rather than the individuals make decisions. More importantly, in his Treatise on the Family (1981, 1991) Becker creates the impression that he has a unified theory of the family. It could be that scholars trained after 1980, who mostly studied Becker's economics of the family from his Treatise, therefore concluded that one can't pick and chose some of Becker's models of the household but not others. The title of the book suggests that. Were it a unified theory it would follow that the chapter on altruism in the family needs to be tied to chapters analyzing various household outcomes, such as fertility and consumption. It would also follow that Becker's own empirical research on household outcomes would be based on the assumption that families are run by men acting as benevolent dictators. This is far from being the case. 
Becker's total set of economic analyses of the family - including the Treatise and all the published articles-does not consist of a unified theory but offers a smorgasbord of models. Of these models, Becker (1965) is a central building block of the NHE, and more so than Becker's unitary model (Becker 1976). Many of the models, including the 1965 model of allocation of time, are compatible with the assumption that individuals in multi-person households make decisions independently as well as with the assumption that households have a benevolent dictator making decisions for all household members. This is especially true of models with testable implications. This holds not only for Becker but also for others in the NHE tradition.

\section{Independent individual decision-making models in the NHE.}

Jacob Mincer is the other founder of the NHE. ${ }^{6}$ The first NHE publications were Becker (1960) on fertility and Mincer (1962) on women's labor supply, articles that recognized the importance of household production. The NHE developed principally in the 1960s at the labor workshop at Columbia University that was directed by both Becker and Jacob Mincer. Here are two statements about the importance of the Becker/Mincer cooperation on the NHE. The first is by Becker: "The decade Jacob and I spent working together was surely one of the most, if not the most exciting and fruitful in my life" (Becker 2006, p. 23). The second statement is by Michael Grossman, who was a student of Becker and Mincer: "Although they never published research together, their interaction with each other and with students at the workshop and the publications that emerged from those interactions (...) resulted in the NHE" (Grossman 2006, p 162).

It is hard to see an impact of Becker's altruism model—published in 1976, 7 years after Becker had left Columbia--on Mincer's contributions to the NHE. Mincer's first articles centered on the concept of household production (Mincer 1962, 1963) include econometric models that can also be derived from independent individual decision-making models, such as Mincer's (1963) equations of women's labor supply and demand for paid domestic services as functions of husband's income and wife's wage. However, Mincer specifically writes that he uses 'total family income' (Mincer 1963) and that "the household, or family, in which income is pooled, is specified as the appropriate decision unit" (Mincer 1993 , p. $x$ ). As a result, he overlooks part of the wife's wage's income effect on her hours of work in the labor force.

After he moved to Chicago in 1969 Becker developed models that are by no means unitary. His marriage models stand out in that respect. Becker's "theory" of marriage contains at least three separate models (Becker 1973 and Chapters 2 and 3 in Becker 1981), and these models all assume that individuals are the decision-makers, not multi-person households.

At least one prediction out of this work has had repercussions in the more recent bargaining and SWF literature: Becker's (1973, 1981 Chapter 2) prediction that sex ratios will affect individual consumption of wives and husbands. Becker's work on divorce (Becker, Landes and Michael 1977, Chapters 10 and 11 in Becker 1981) is also mostly consistent with independent individual decision-making assumptions.

Other Beckerian household decision-making models, such as Becker's fertility models (including Becker 1960 and Becker and Gregg-Lewis 1973) have household utility functions but they are vague as to the structures binding households. Generally, there is no

\footnotetext{
${ }^{6}$ See Grossbard-Shechtman (2001) for more on the history of the NHE.

${ }^{7}$ More on these separate models of marriage is found in Grossbard (2010).
} 
reference to the benevolent altruist in most of Becker's empirical research on outcomes of household decisions, including most family behaviors singled out by the Nobel committee. This applies to his work on marriage, on fertility, and divorce. In his empirical articles, I would describe Becker's approach to household decision-making as pragmatic in that it does not impose any structure on whether households make their decisions jointly or separately. In all of his work on marriage and divorce he recognizes individuals as separate and often independent decision-makers.

Michael Grossman has become a world-reknown health economist. His dissertation at Columbia, written under the guidance of Becker and Mincer, included a model of health production in the household and was eventually published as Grossman (1976). Again, this model is of a pragmatic nature, making no assumptions as to the distribution of health produced in a household or whether men and women play any cooperative or noncooperative games when investing in the human capital that helps them fight illness. He tested how his resources and her resources - including each partner's education levelsaffected both his health and her health. This is not an empirical approach based on a unitary model. Until this day, Grossman's independent individual model of the production of health at home is widely cited in the literature in health economics but often misnamed the Human Capital model (rather than the home production or NHE model, see Anderson and Grossman 2009). Another student writing his dissertation under Becker and Mincer, Robert T. Michael, analyzed productivity in household production (see Michael 1973), with a focus on the effect of education on that productivity.

Becker's economic analyses of marriage inspired a number of students writing their dissertations on marriage under his guidance at Chicago in the 1970s, including Alan Freiden (see Freiden 1974), Michael Keeley (see Keeley 1977), and me. In my dissertation on the economics of polygamy in Nigeria, I developed a model of household decision-making that considers spouses as independent decision-makers supplying or demanding work in household production. It is closely related to Becker's Demand and Supply models of marriage as well as to traditional labor economics models. This Demand and Supply analysis of women's household production work for the benefit of husbands included the concept of wife-wage (called 'quasi-wage' in gender-neutral later writings; see Grossbard 1976). I developed this model into a general equilibrium model of individual allocation of time in multiple markets for labor and marriage in Grossbard-Shechtman (1984).

Based on Becker's Demand and Supply models of marriage, Grossbard-Shechtman (1984) assumes that individuals remain independent decision-makers after marriage as far as their supply of labor and their demand for goods are concerned. This article includes predictions that there will be compensating differentials in marriage and that sex ratios will affect individual labor supply. Later, the bargaining/SWF literature also obtained Becker's prediction regarding sex ratio effects on consumption (see McElroy 1990) and my prediction regarding sex ratio effects on labor supply (see Chiappori, Fortin, and Lacroix 2002). The concept of compensating differentials in marriage developed in my model assuming independent individual decision-makers (Grossbard-Shechtman 1984) has been derived by Chiappori based on his SWF approach and has recently been analyzed empirically by Chiappori, Oreffice and Quintana-Domeque (2010).

\section{Becker's models and his students at Chicago in the 1970s}

Even though they were published around the same time as his independent individual models of marriage-in the period 1965-1976--Becker's unitary model of a benevolent altruist (Becker 1974 and Becker 1981, Chapter 8) did not have much success 
among students. The same holds for his sociobiological model (Becker 1976 and Becker 1981, Chapter 8), justifying gender differences based on biological factors, published around the same time. Students interested in economics of the family at Chicago in the 1970s realized the coexistence of Becker's many models of household decision-making. As firstyear students we got to know Becker in his price theory course packed with a variety of maximization models and aimed at getting us to practice his specialty: applying calculus to everything. The message was: "Identify a utility function and some constraints and do some calculus". A few of us also learned Beckerian household models in Gregg-Lewis' labor supply courses he taught in 1974, some of which were developed by Gregg-Lewis but never published. ${ }^{8}$ Gregg-Lewis also mentioned Glen Cain's research in which he estimated income's effect of husband on wife's labor supply separately from the effect of non-labor income in the household (see Cain and Dooley 1976). We also learned about Cain's earlier empirical research on labor supply (Cain 1966). Such an independent individual model appeared to be in the tradition of the NHE even though Cain had not studied or worked with Becker or Mincer. We also got to learn some NHE models of the household from Jacob Mincer, who was a visiting professor at Chicago during the period 1974-1975.

Becker offered his course on the economics of the family for the first time in 197576, while he worked on his Treatise on the Family, which eventually got published in 1981. Again, Becker showered students with what seemed like an endless stream of optimization models, but this time they all addressed issues related to household economics. One of the models was the benevolent dictator model. It was applied in the context of intra-household transfers.

Students interested in economics of the family also participated in Becker's workshop on Applications of Economics. I did so in the years 1974-1976. That Becker's various models coexisted and did not have to be integrated into one whole was obvious from some of the discussions that went on in Becker's workshop during this period, including a discussion on Becker's various models of marriage in which Ed Lazear also participated.

In his workshop Becker gave a voice to the proponents of nascent game theories of marriage. Louis Wilde, a student at Rochester, presented a paper on marriage using Nash equilibrium in Becker's workshop in 1975. Marjorie McElroy did a post-doc at Chicago, invited by Becker, around 1977. During this time she worked on her influential bargaining theory of marriage (McElroy and Horney 1981). ${ }^{\text {? }}$

Overall, the approach at Chicago in the 1970s was pragmatic: if a model helps develop interesting testable implications, it is worth keeping. All theoretical models are welcome, as long as they 'work'. There was no sense that Becker has a unified theory of decision-making in households. We as students got the impression that Becker is a virtuoso, a brilliant performer on the academic stage, able to produce a variety of thought-provoking models. The messages were: "It is OK to choose the model most appropriate for studying the issues you are researching" and "Good economists can pick and choose their models, depending on what works best." We were not expected to integrate Becker's various models. There was no pressure on students to accept Becker's argument that there are good biological reasons why women should do more of the household production than men (see Suzanne Bergeron's (2009) critique on Becker's model that assumes a male breadwinner/female care worker division of labor, a model found e.g. in the Treatise). Nor was there pressure to adopt the unitary model of an altruistic household head. Personally, I was eager to dissociate myself

\footnotetext{
${ }^{8}$ See Grossbard-Shechtman (2003) for models based on that course.

9 More on this topic in Grossbard (2010, forthcoming).
} 
from the sexist assumptions of Becker's sociobiological theories and the assumptions of the Rotten Kid theorem, which bothered me both as a feminist and as a strong advocate of family democracy. At the same time, I enthusiastically endorsed Becker's individual models of marriage and used them as the basis for my own modeling. Woolley (1996) also recognizes that it is possible to separate Becker's various models and adopt some but not all.

Those who learned about Becker's models of decision-making in households after 1980 , even if they studied at Chicago, have probably received a different perception regarding the possibility of including independent individual models in analyses in the NHE tradition. By then, Becker had published his Treatise, in which he tried to convey a sense that he has a unified theory; Gregg-Lewis, who had taught Beckerian models with an independent individual approach and with heavy emphasis on parallels between households and firms, had left Chicago; and Mincer-having rejected Chicago's offer to join the economics department as a full professor--did not teach at Chicago. Unitary models of Becker may have been perceived as even more central to his opus on the family from the perspective of scholars trained outside Chicago after 1980.

\section{Conclusions}

Other than Becker's, the most widely cited theoretical models of decision-making in households are mostly bargaining models and consensual models. These models avoid flaws of unitary models, such as the anonymity implication and the lack of concern for external factors such as marriage market conditions measured by sex ratios. These models often place themselves in contradistinction with Becker's unitary models and the NHE tradition that Becker co-founded with Jacob Mincer.

It has been argued in this chapter that most of Becker's own analyses of the family did not use his unitary model. Many of the models by Becker, Mincer, and other researchers in the NHE tradition are consistent with the assumption that individuals in families act independently, although their decisions may depend on resources and prior decisions by their spouses or other household co-members. Becker's marriage models include specifically independent individual models. Decision-making models assuming independent individual household members in the Becker tradition, such as Grossbard-Shechtman (1984), are reminiscent of models of labor markets in which firms and workers are independent decision-makers. As basis for econometric estimations, such models may be preferable to models imposing the structure of a game or a household welfare function.

Given the low profile of unitary models in the work of Becker and Mincer-the founders of the NHE--, their students and other NHE contributors, and the fact that important parts of the NHE consist of models that are either explicitly assuming independent individual models of household decision-making or compatible with that assumption, it is time to dissociate the NHE and unitary models. It is time to give the NHE tradition more credit for its decades of wide-ranging productive research on labor supply, consumption, marriage and divorce and to take more seriously early models developed prior to the publication of bargaining and SWF models.

ACKNOWLEDGMENTS: I thank the editor, Alberto Molina, and Elena Stancanelli for helpful comments on the chapter. Conversations with Barry Chiswick and Michael Grossman-two scholars who were part of the development of the NHE--reinforced my view that unitary models played a minor role in the NHE. 


\section{References}

Anderson, Richard and Michael Grossman. (2009) "Health and the Household" Review of Economics of the Household 7(3):219-226

Apps, Patricia F. and Ray Rees. 1988. "Taxation and the Household." Journal of Public Economics 35:355-369.

. (2009), Public Economics and the Household, Cambridge: Cambridge University Press.

Becker, Gary S. 1960. "An Economic Analysis of Fertility." In National Bureau Committee for Economic Research, Demographic and Economic Change in Developed Countries, a Conference of the Universities. Princeton, N.J.: Princeton University Press.

. 1965. "A Theory of Allocation of Time.” Economic Journal 75:493-515.

1973. "A Theory of Marriage: Part I." Journal of Political Economy 81:813-846.

. 1974. "A Theory of Social Interactions." J of Political Economy 82(6): 1063-93.

. 1976. "Altruism, Egoism, and Genetic Fitness: Economics and Sociobiology." Journal

of Economic Literature 14 (3): 817-826.

. 1981. A Treatise on the Family. Cambridge: Harvard University Press, first edition.

1991. A Treatise on the Family. Cambridge: Harvard University Press, second edition.

2006 "Working with Jacob Mincer: Reminiscences of Columbia’s Labor Workshop"

in Shoshana Grossbard (ed.),Jacob Mincer: A Pioneer of Modern Labor Economics. New York: Springer.

Becker, Gary S., Elizabeth Landes, and Robert Michael. 1977. "An Economic Analysis of Marital Instability." Journal of Political Economy 85: 1141-88.

Becker, Gary S. and H. Gregg Lewis. 1973. "On the Interaction between the Quantity and Quality of Children.” Journal of Political Economy 81(2, pt. 2): S279-S288.

Bergeron, Suzanne. 2009. "An Interpretive Analytics to Move Caring Labor Off the Straight Path"Frontiers: A Journal of Women Studies - Volume 30, Number 1, pp. 55-64

Bergmann, Barbara R. "Becker's Theory of the Family: Preposterous Conclusions" Feminist Economics 1(1): 141-150, 1995.

Bloemen, Hans G. and Stancanelli, Elena F. G. (2008), "How do spouses allocate time: the impact of wages and income", IZA DP No. 3679, September. 
Borjas, George (2009) Labor Economics. New York: McGraw Hill Irwin.

Browning, Martin, Francois Bourguignon, Chiappori, Pierre-Andre, and Valerie Lechene (1994), "Incomes and Outcomes: A Structural Model of Intra-Household Allocation." Journal of Political Economy 102(6): 1067-1096.

Cain, Glen G. (1966) Married Women in the Labor Force: An Economic Analysis. Chicago: U of Chicago Press.

Cain, Glen G. and Martin D. Dooley (1976) "Estimation of a Model of Labor Supply, Fertility and Wages of Married Women.” Journal of Political Economy 84 (4): S179S200.

Chau, Tak Wai, Hongbin Li, Pak Wai Liu and Junsen Zhang (2007) “'Testing the collective model of household labor supply” China Economic Review Volume 18, Issue 4, pp. 389-402

Chiappori, P.-A. (1988). Rational household labor supply. Econometrica 56, 63-90.

Chiappori, P.-A. (1997). Introducing household production in collective models of labor supply. Journal of Political Economy 105, 191-209.

Chiappori, P.-A., B. Fortin \& G. Lacroix. (2002). Marriage market, divorce legislation, and household labor supply. Journal of Political Economy, 110, 37-71.

Chiappori, P.-A. , S. Oreffice and C. Quintana-Domeque. (2010). «Fatter attraction : anthropometric and socioeconomic matching on the marriage market" Paper presented at the IFS workshop, London, June.

Connelly R. and J. Kimmel (2010), 'Spousal Influences on Parents' Non-Market Time Choices", Review of Economics of the Household, Springer on line first.

Ehrenberg, Ronald G. and Ronald Smith (2009), Modern Labor Economics. Addison-Wesley.

Emerson, Patrick M. and André Portela Souza (2007) "Child Labor, School Attendance, and Intrahousehold Gender Bias in Brazil” The World Bank Economic Review 2007 21(2):301-316.

Freiden, Alan. 1974. "The U.S. Marriage Market." In Economics of the Family, edited by T.W. Schultz. Chicago: University of Chicago Press.

Grossbard, Amyra. (1976). "An Economic Analysis of Polygamy: The Case of Maiduguri." Current Anthropology 17:701-7.

Grossbard-Shechtman, Amyra. 1984. "A Theory of Allocation of Time in Markets for Labor and Marriage." Economic Journal 94:863-82. 
Grossbard-Shechtman, Shoshana A. 1993. On the Economics of Marriage. Boulder, CO: Westview Press.

. 2001. "The New Home Economics at Columbia and Chicago." Feminist Economics $7(3): 103-130$.

Shoshana Grossbard-Shechtman (2003). "A Consumer Theory with Competitive Markets for Work in Marriage," Journal of Socio-Economics, 31(6): 609-645.

Shoshana Grossbard. (2010). “How ‘Chicagoan' are Gary Becker's Economic Models of Marriage?” J of History of Economic Thought, forthcoming.

Grossman, Michael (1976), "The Correlation between Health and Schooling." In Household Production and Consumption, edited by N. Terleckyj. New York: Columbia University Press, for the National Bureau of Economic Research.

. (2006) "Household production and health" in Shoshana Grossbard (ed.),_Jacob Mincer: A Pioneer of Modern Labor Economics. New York: Springer.

Katz, Elisabeth (1997) “The Intra-Household Economics of Voice and Exit" Feminist Economics, Vol 3 Number 3 , pages 25 - 46

Klawon, ]. Emily and Jill Tiefenthaler (2001) "Bargaining over family size: The determinants of fertility in Brazil", Population Research and Policy Review, 20: 423-440.

Keeley, Michael C. 1977. “The Economics of Family Formation.” Economic Inquiry 25:238250.

Konrad, Cai and Kjell E. Lommerud (1995). "Family Policies with Non-Cooperative Families.” Scandinavian J of Economics 97(4): 581-601.

Lundberg, Shelly and Robert A. Pollak. 1993. "Separate Sphere Bargaining and the Marriage Market.” Journal of Political Economy 101:988-1010.

Manser, Marilyn and Murray Brown. 1980. "Marriage and Household Decision Making: a Bargaining Analysis." International Economic Review 21:31-44.

McElroy, Marjorie B. and Mary Jane Horney. 1981. "Nash Bargained Household Decisions: Toward a Generalization of the Theory of Demand." International Economic Review 22:33349.

McElroy, Marjorie B. 1990. "The Empirical Content of Nash-Bargained Household Behavior" Journal of Human Resources 25:559-83.

Michael, Robert T. 1973. "Education in Non-Market Production." Journal of Political Economy 81(2): 306-327. 
Mincer, Jacob. 1962. "Labor Force Participation of Married Women: a Study of Labor Supply," in H. Gregg Lewis (ed.) Aspects of Labor Economics. Princeton, N.J.: Princeton University Press.

. 1963. "Market Prices, Opportunity Costs, and Income Effects," in C. Christ (ed.) Measurement in Economics. Stanford, CA: Stanford University Press.

. 1993. Studies in Labor Supply: Collected Essays of Jacob Mincer, Volume 2. Aldershot, England: Edward Elgar.

Robbins, Lionel (1930), "On The Elasticity of Demand For Income in Terms of Efforts." Economica 10:123-29.

Samuelson, Paul. 1956. "Social Indifference Curves." Quarterly J. of Economics 70(1):1-22.

Schwarz Peter M., Jennifer L. Troyer, and Jennifer Beck Walker 2007, “Animal House: Economics of Pets and the Household", Berkeley Electronics Journal of Economic analysis and policy 7(1):

Tiefenthaler, Jill (1999). “The Sectoral Labor Supply of Married Couples in Brazil: Testing the unitary model of household behavior.” J of Pop Econ 1999 12: 591-606

Woolley, Frances (1996), "Getting the Better of Becker." Feminist Economics 2:114-120. . (2003), "Control over Money in Marriage." in Shoshana Grossbard-Shechtman (ed.) Marriage and the Economy. New York: Cambridge University Press. 